

\section{Progress Raport}

TRAFFIC SPBED RSPCRT 10, 72

201

FaOt:
K. B. Koods, Director

Jolnt Hil ginay Plosearch Project

H. L. Hebel, Assistant Director

Joint Highay Research Project
Novertbar 2, 1960

F1] 8-3-3

Project: $c-36-10 \mathrm{C}$

Attached is the 7lat progress roport on vohicla speeda which has been properod by this Project. The current ruport "Iraffie Spoed Roport No. 7." has boen authored by Forreat D. Wiler, graduato asoietant on our stafe.

The reaults of this latest study indiceta a continuation of the inereaging opeed trend fce free-moving vohielas on level, tangent sections of rural highey.

This report is also scheduled for distribution to tha Buroau of Publie Roeds, the Indiana State Police, the Indiana Orfice of Traffic Safoty and the Traffic Bnglneering and Planning sections of the State Highray Department of IndSana. distribution.

The report is presented for the record and for release for Feopectruly aubaifted,

Tomeld thuahel

Herold Is Mehaol, Secrotary

HLAvame

Attacheant

ee: P. I. Ashbauchor

J. R. Coopor

J. F. Melaughlen

W. I. Dolch

R. D. Kilas

V. H. Coetz

R. E. Kuvo

G. A. Haviding (K. B. Scott)

C. B. Vogelgoang

7. F. Havay

J. Is halling

G. A. Ieonards

J. B. W1100a

B. J. Yodor 
Progress Raport

TRATIC SFBSD RBPCR? nO, $n$

\author{
by
}

Forrest 2 G170r

Grsduata Aasistant

Jolnt Highray Reooarch Projoct

FI] : $8-3-3$

Projoct: Co-36-10C

Purtwe University
Lafayetts, Indiana

November 2, 1960 


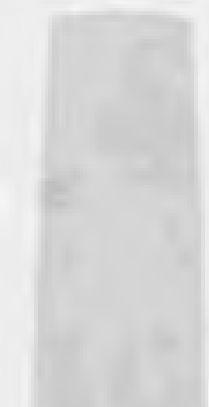

Digitized by the Internet Archive in 2011 with funding from LYRASIS members and Sloan Foundation; Indiana Department of Transportation

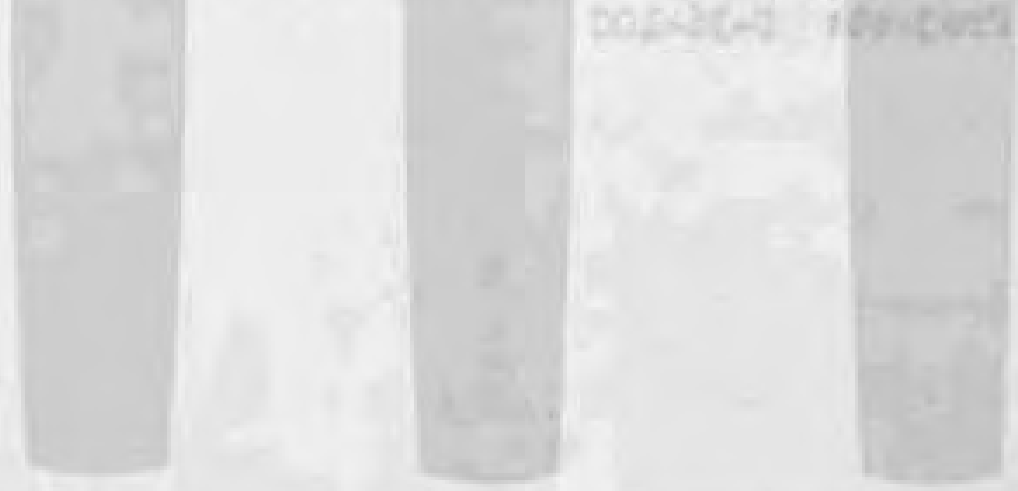




\section{IIST OF TABUES AND FIGURES}

DARIRS

TABIB NOO.

SLAMARY OP SPOR SPBED OBSERVATION ......... I I I. I

V.S. 52 - $1.0 \mathrm{kIIB}$ SOUTH UP S. JCI. S.R. $28 \ldots$. . II

U.S. 52 - 1.0 iItR kSST OF ITOMDTRE. ....... III

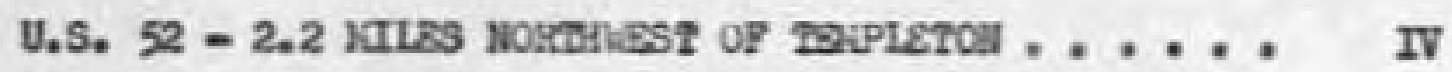

U.S. $32-7.2$ ktuzs worah of ParersBuna, . . . . . v

S.R. $25-0.7$ zIIS SOUTH of AVERTCLS . . . . . . VI

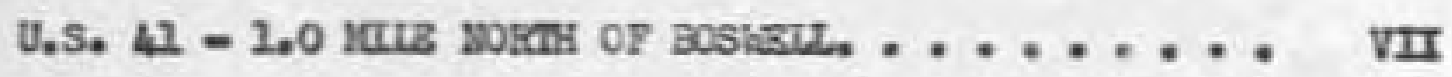

\section{PIGUizS}

Brates 10.

PSRCEIrII SPED CURVES

U.S. 52 - 2.0 uTLZ SOUTH OR S. JCT. S.R. 28. . . . 1

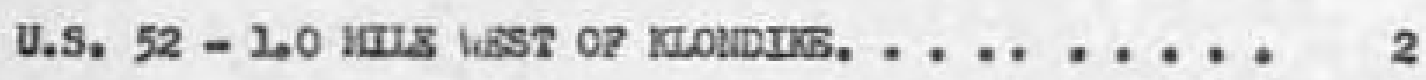

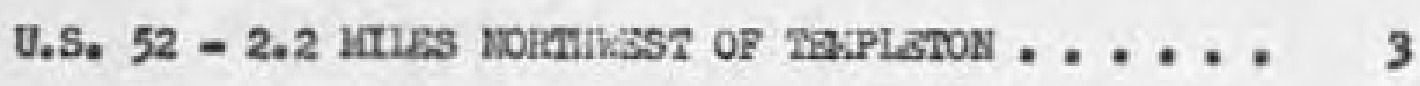

U.8. $31-7.2$ หIJIS NoRTH OP PBRRISBURG. . . . . 4

S.R. $25-0.7$ HIL SOUNH OF ALZRTCUS . ...... 5

U.S. 41 - $1.0 \mathrm{MIUE}$ NORTH OF BCBNRLT. ....... 6

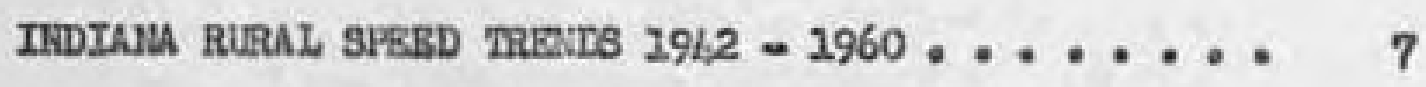

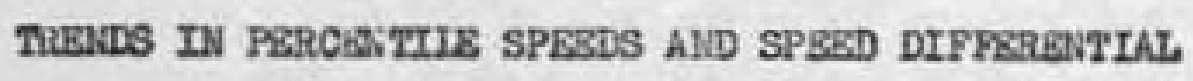

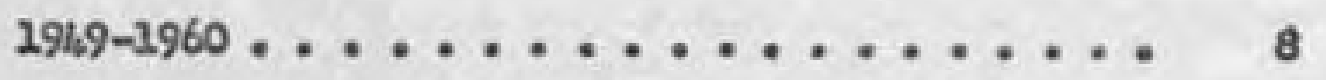


TRAFIC SPBSD RRPCRZ NO, 72 .

This ropcrt covers spot speed obeervations min during Auguet and Septamber 1960. All observations vore ande of frve moving vohicles on level tangent sectilons of rural highays. The locations of the stations wero the sasa as for previous studies and aro as follows:

1. U.S. $52-1.0$ anle south of south junetion of S.R. 28 (dual lanas)

2. U.S. $52-1,0$ alle vost of Kondiles (dual lanas)

3. U.S. $52-2.2$ miles northvest of Tursplaton (2 lanes)

4. U.5. $32-7.2$ miles north of Perryeburg (2 lanas)

5. S.ll. $25-0.7$ mile south of Aborleus (2 lanas)

6. U.S. $41-1.0$ mile north of Bonoll (2 lanes)

An Blactrorntie Hadar Speed Mater wes used to collact the data for this study. The meter was concealed as part of a rural mailbox and placed noar the edge of the paverent. It was directod along the highnay at a small anglo vith respect to the direction of traffle so that It was not necassary to malse angle corrections to the readingse The redse equipment uged will not operete properly if the voltage varlos more than manus $1 / 2$ volt or plus 2 volt from the optinum tunelvo volte. The valtage vas therefore checked poriodically in the Fleld and maintained vithin the deslred range. 1200 , correct callibration was mintalinod by periodically checlding 1t with a 60 millo per hour tuning forke

Th obsorvors concealed thansolvos from traffic as meh as local conditions perritted. It is thus belloved that the speede of 
the observod vehicles vere not influenced by the observor or the equipenent.

A sumary of the results of this study, as vell as of the last seven studies, Is given in Table I. Indiara Stato Lav 21nits the speed of passenger cars and trucks under 5,000 pounds (GVi) to 65 mlles per hour. The speed limit of trucks over 5,000 pounda (Gn:) is 50 mlles per hour an all highnays except that on 4 -lane highays, which have a nedian strip of at loat tventy feet in uddh, the speed limit is 55 allos por bour. Inis latter spead lint for trueks has boen in offect alnee about Vay 1959. Lost truek speed 14idt sigrs posted along the state highays reflect this change and it is probablo that a large portion of the truck drivere are aarare of this speed linit changs.

Truck speads are shown in the tables for three groups: light trueks, heavy trucks, and all trucks. Spoods aro also shown soperately for 2-lane and L-lano highays. All 4-lsne obeervation stations were on highways with a mdian of greater than twenty feot. Since voights were not taloen in this study, light trucke (less than 5,000 pounds) were considared to be on $2 y$ panel trucks and pick-up trucks. All other types of trucks vere classifled as haavy (over 5,000 pounds).

The pesoonger car data were also classifiod into three groups: Indlana, out of state, and all paseengor caro. The classification was detemined by observing the license plate on each passanger car passing the observation stations.

A ecciparieon betwoon the results of the prosent study and those of the leet previous study (Alarch-hpre11 1960) is presentod in Tables II through VII. Awrege and 85th peroantile opeede worv ocnputed for esch whiclo group from the eanple of rohicles taken at each study site. 
The avorage speed for all passenger cars was $2.4 \mathrm{mll}$ ses per hour faster then that obtainod in the last study whilo average speeds for all trucke vas 2.7 milles per hour higher than in larch-lpri2 2960. Indiana paesengor carv had an average spoed on 2-3ano highays 2.4 filos per hour faster vhilo their avorage apead on L-2are highnays inereesed by 1.4 mllas por hour. Out-of-state pessenger cars Increased their avarage speed on 2-1rm hinays by 0.8 alles por hour while their average speed on 4-lane highays increaged by 2.0 mile por hour.

The average epeod for light trucks increased by 4.5 atles per hour en 2-lane highrays and 2.4 miles per hour on 4 -lane highnays. For heavy trucks the average speed increaged by 2.2 mlles per hour on 2-lare highaye and 4.0 atlos per hour on 4 -lane highrays.

The 85th porcentile speed for all pasenger cars increaeed 0.7 mile por hour.

Trond Inforration on the average speede of paveengor cars and trucks and on the 85th porcentile speed for pussenger cars is shown in Tablo I and FIguro 7 and 8. Table I is a surmary of spot apeed observations on Indlam highuays for the last of ght studies (since August 1956). This sumery lists the observations for two-lane mighrays, four-lane hichways, and all highways for both passenger cars and trucks.

FIgure 7 is a graph shailng rural speod tronds from 1942-1960 for both passenger ears and trucks.

Figure 8 is a graph shoiding trends in percontile speeds and speed differential from 1949-1960 for both passenger cars and hoavy trucks. The speed difforentinl is tho difference between the 85th percantile of pessanger cars and 15th percentile of heavy trucks. 


\section{TABIE I}

SUMAMAXY OF SPOT SPBED OBSERVATIONS

ON INDIANA HTGWAYS

(Pres-Noving Vehicles on Level, Tangent Sections)

\begin{tabular}{|c|c|c|c|c|c|c|c|c|}
\hline & \multicolumn{4}{|c|}{ Pasgenter Caxs } & \multicolumn{3}{|c|}{ Truale } \\
\hline & & $\begin{array}{l}\text { Ind } \\
\text { Noan }\end{array}$ & $\begin{array}{l}\text { Mon-Ind } \\
\text { Moan }\end{array}$ & $\begin{array}{l}\text { AII } \\
\text { Jaan }\end{array}$ & $\begin{array}{l}\mathrm{A} 21 \\
85 \mathrm{per}\end{array}$ & $\begin{array}{l}\text { Ifght } \\
\text { Magn }\end{array}$ & $\begin{array}{l}\text { Heavy } \\
\text { Yean }\end{array}$ & $\frac{A I I}{\text { Yean }}$ \\
\hline \multirow[t]{8}{*}{$\begin{array}{l}\text { Tro-tano } \\
\text { Highways }\end{array}$} & Aug. 156 & 55.0 & 56.3 & 55.5 & 63.4 & 50.6 & 45.5 & 46.6 \\
\hline & $\mathrm{Hay} 157$ & 55.6 & 59.2 & 56.9 & 64.0 & 50.2 & 44.8 & 46.1 \\
\hline & Aug. 157 & 55.5 & 56.7 & 55.9 & 62.1 & 52.7 & 45.8 & $47 \cdot 3$ \\
\hline & Aug. '58 & 54.3 & 56.3 & 55.0 & 61.7 & 53.0 & 46.3 & 47.8 \\
\hline & lar. 159 & 55.5 & 57.7 & 56.1 & 61.9 & 50.4 & 45.4 & 46.3 \\
\hline & Aug. 159 & 55.6 & 55.3 & 55.9 & 63.2 & 49.7 & 46.7 & 48.0 \\
\hline & Mar. 160 & 53.3 & 54.8 & 53.7 & 61.2 & 48.5 & 45.9 & 46.6 \\
\hline & Sept. 160 & 55.7 & 55.6 & 55.6 & 62.0 & 53.0 & 48.1 & 49.1 \\
\hline \multirow[t]{8}{*}{$\begin{array}{l}\text { Pour-Iana } \\
\text { Highways }\end{array}$} & Aug. 156 & 57.4 & 58.8 & 58.2 & 66.8 & 49.6 & 46.0 & $47 \cdot 4$ \\
\hline & Nay 197 & 59.9 & 63.6 & 61.0 & 69.0 & 52.2 & 46.0 & $47 \cdot 9$ \\
\hline & Aug. ${ }^{057}$ & 57.5 & 59.9 & 58.5 & 64.8 & 52.0 & 46.6 & 47.6 \\
\hline & Aug. 158 & 58.0 & 59.6 & 58.7 & 65.0 & 54.3 & 4900 & 50.0 \\
\hline & Mar. 159 & 58.2 & 61.7 & 59.0 & 64.9 & 53.6 & 47.0 & 48.4 \\
\hline & Aug. 159 & 58.4 & 60.1 & 59.1 & 64.5 & 50.0 & 53.1 & 49.5 \\
\hline & Mar. 160 & 58.1 & 59.2 & 58.4 & 65.0 & 52.4 & $47 \cdot 3$ & 48.4 \\
\hline & Sept. ${ }^{\circ} 60$ & 59.5 & 60.2 & 59.7 & 65.8 & 54.8 & 51.3 & 52.0 \\
\hline \multirow[t]{8}{*}{ Hil ghwayo } & Aug, 156 & 55.7 & $57 \cdot 3$ & 56.4 & 64.5 & 50.2 & 45.6 & 46.9 \\
\hline & Lay 197 & 57.2 & 60.3 & 58.3 & 66.0 & 50.9 & 45.2 & 46.6 \\
\hline & Aug. 157 & 56.2 & 58.3 & 56.9 & 63.2 & 51.8 & 46.1 & $47 \cdot 4$ \\
\hline & Aug. 158 & 55.7 & 57.9 & 56.5 & 63.1 & 53.4 & 47.5 & 48.7 \\
\hline & Kar. 159 & 56.6 & 59.0 & $5 \% \cdot 2$ & 63.1 & 51.5 & 45.5 & 47.0 \\
\hline & Aug. '159 & 56.5 & 58.4 & 57.4 & 63.5 & 50.6 & 47.8 & 48.6 \\
\hline & Nar. 160 & 55.6 & 57.1 & 56.0 & 63.0 & 50.2 & 46.6 & 47.5 \\
\hline & Sept. 160 & 57.3 & 57.6 & $57 \cdot 4$ & 63.7 & 53.7 & 49.4 & 50.2 \\
\hline
\end{tabular}




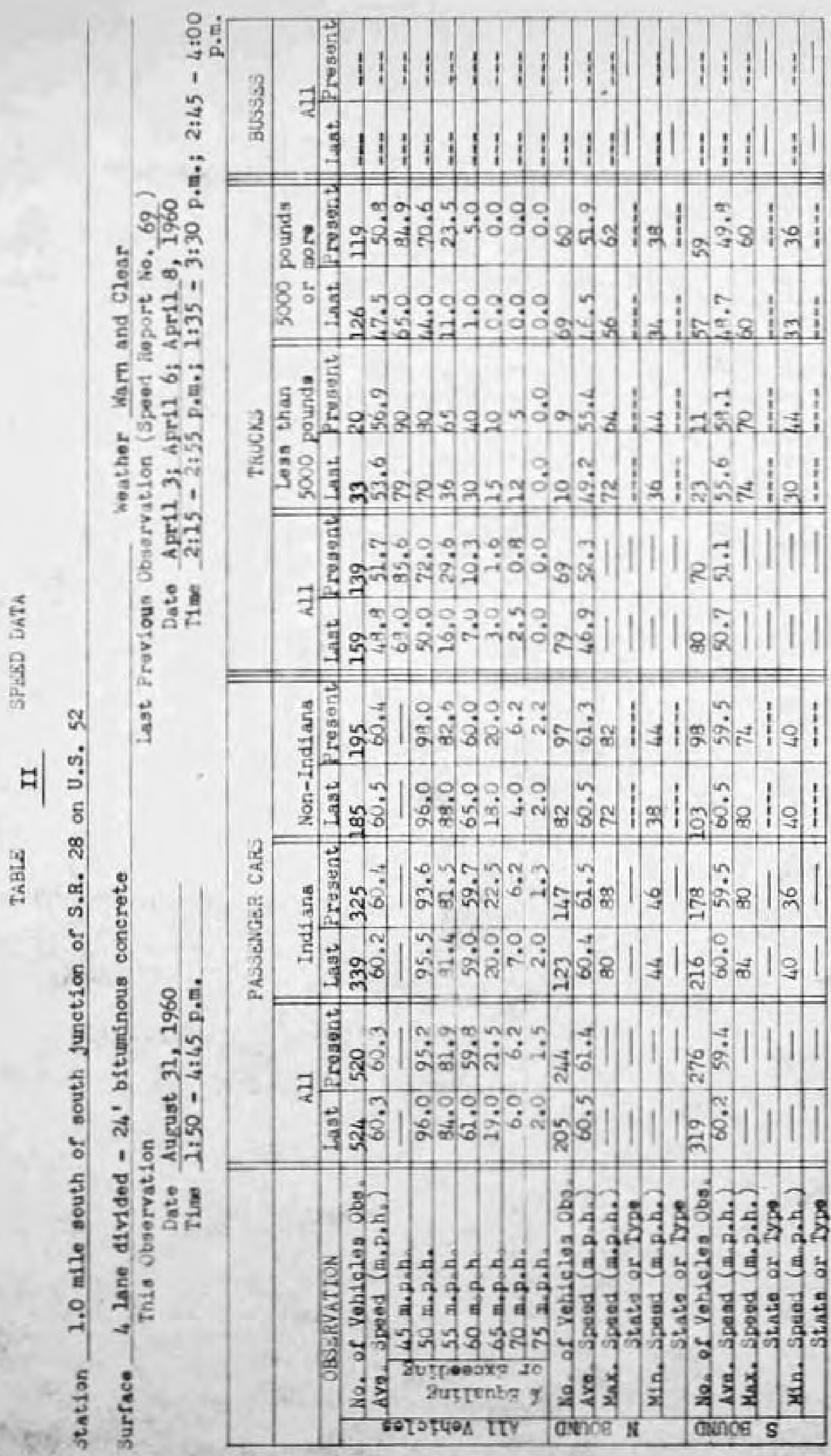




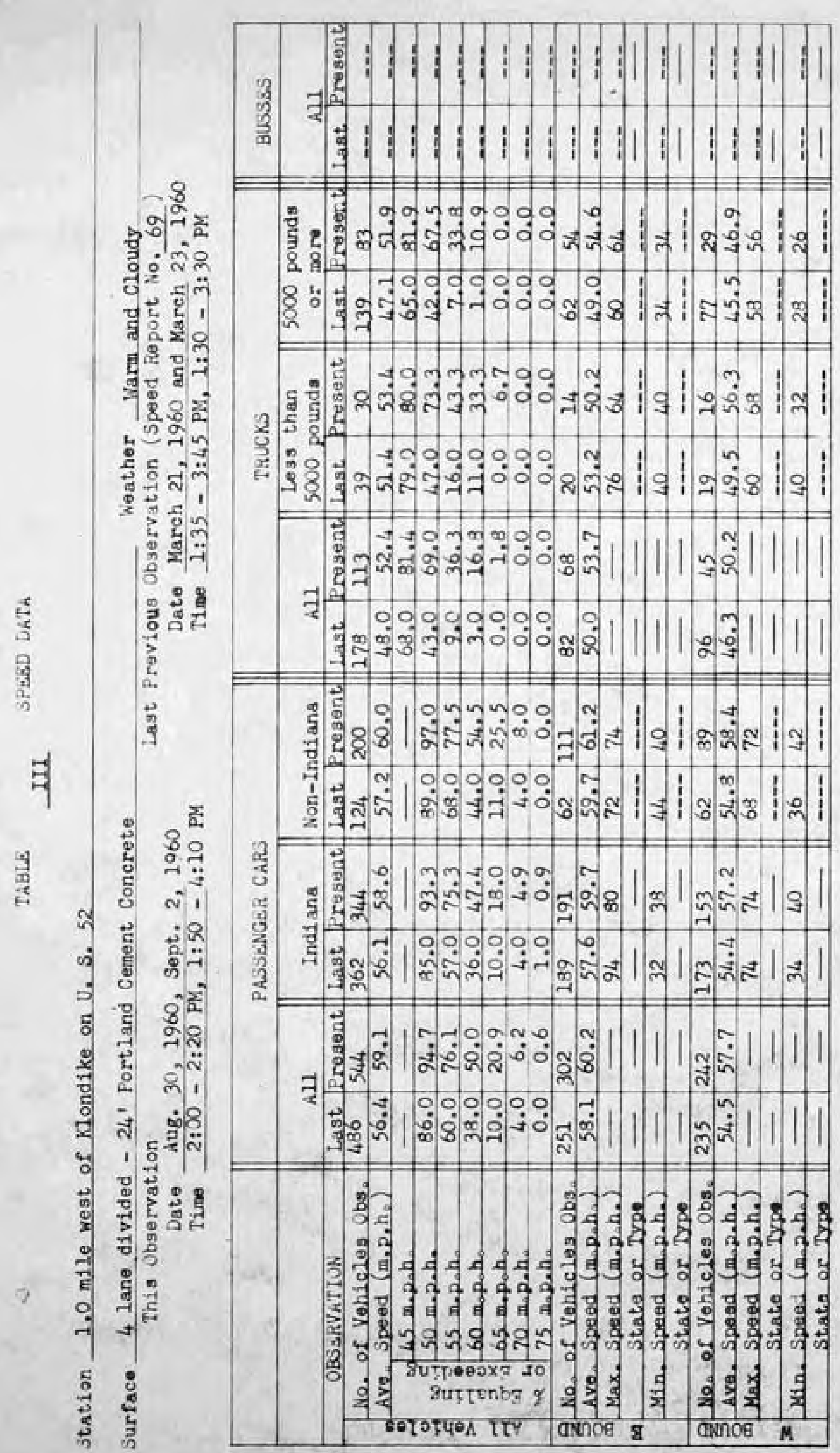




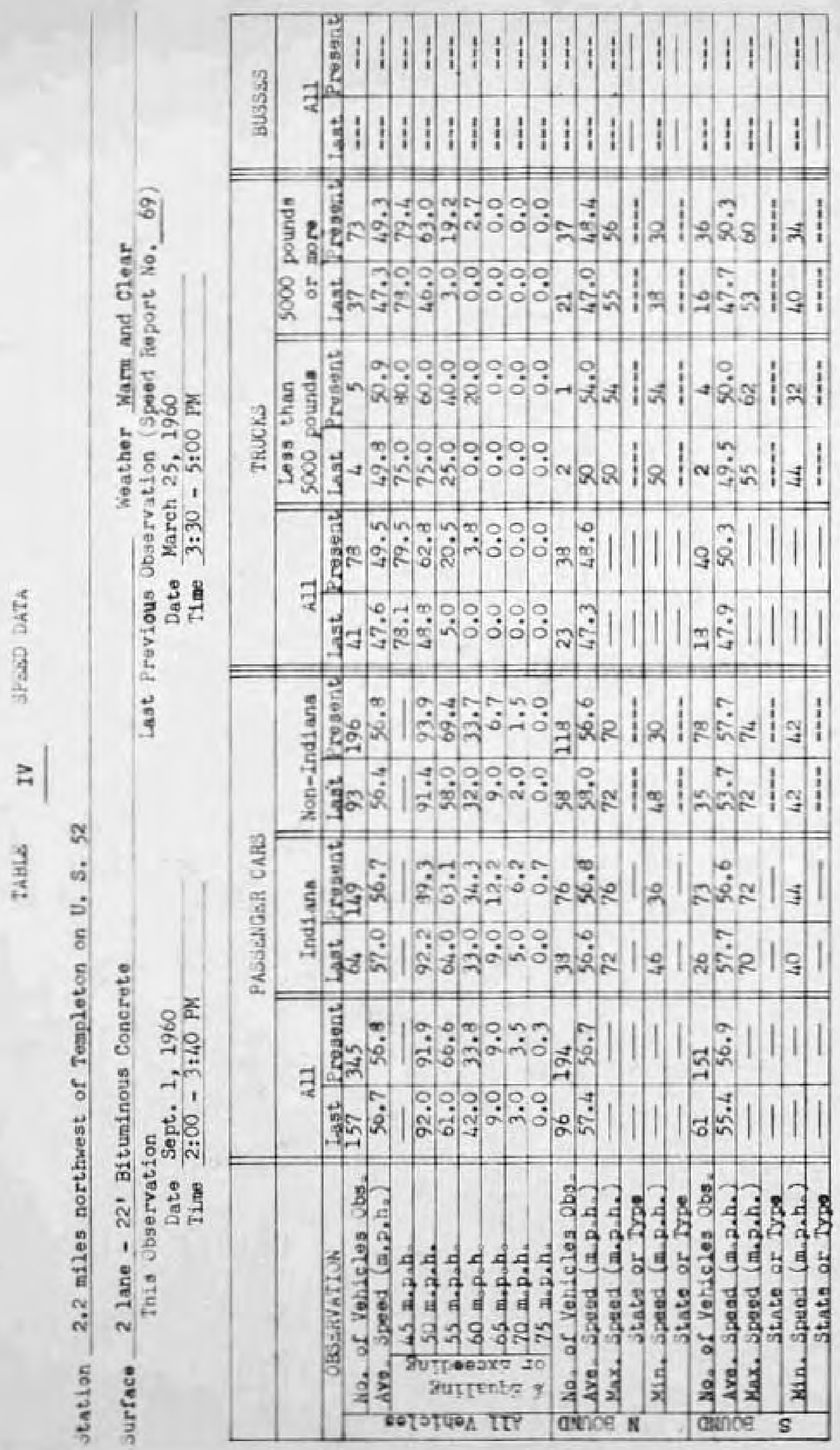




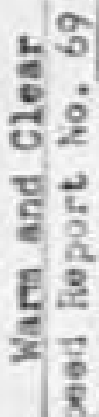

का $2 \frac{2}{2}$

ᄂ)

उै

क्जि

$>$ 넌

远先

学

5

S

题音

ติ

है

8 宛

गิ

है इ ल

与

c 藏品

s

돌

ga日

9 1 ह

है

है

$\frac{n}{2}$

. $\mathrm{N}$ है

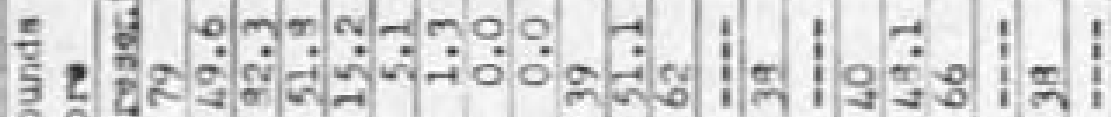

8 a $=$ molooloo

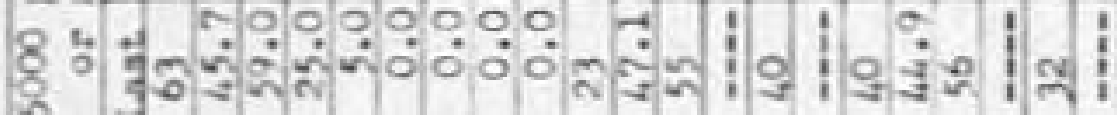

3

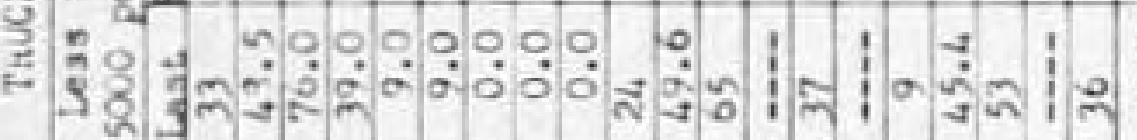

c

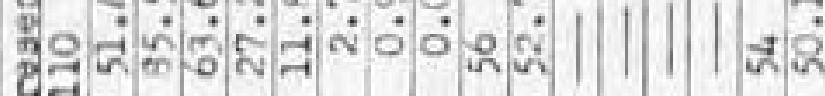

$-14 \pi$

과

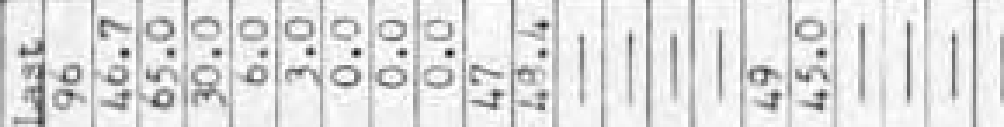

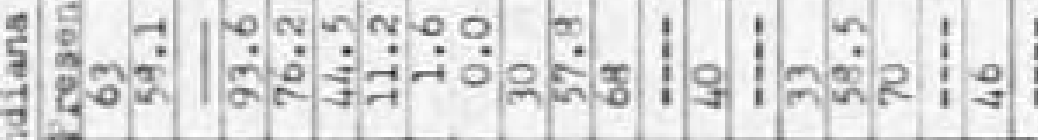

|

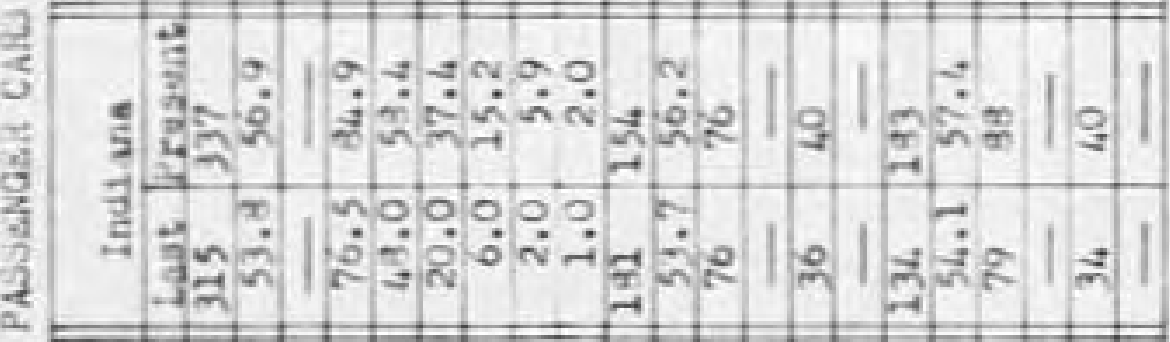

?

G⿱艹

चี

gी

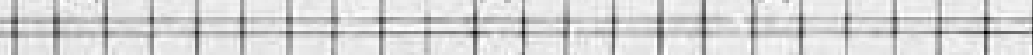

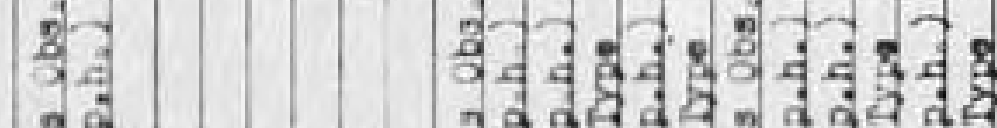

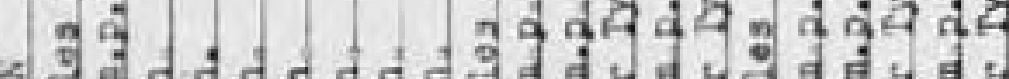

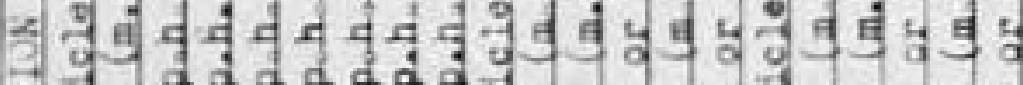

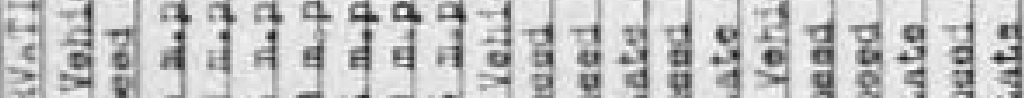

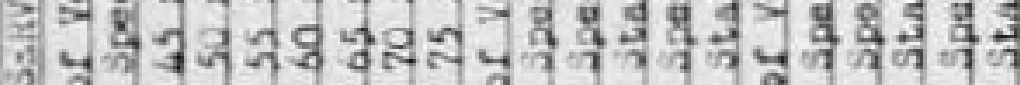

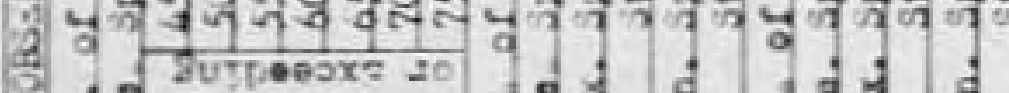

进年


a

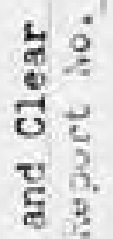

要

$\sin 2$

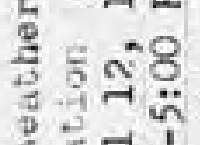

एँ

के

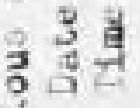

等

2

$\dot{5}$

it

:

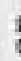

वे

4

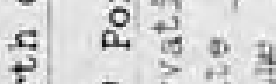

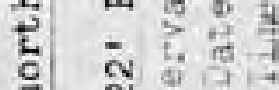

c N

常

(2)

3

8 五:

$\rightarrow-1$

$\div 1$

$\dot{2}$

ㄷํㅇำ

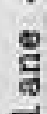

$\frac{3}{2}$

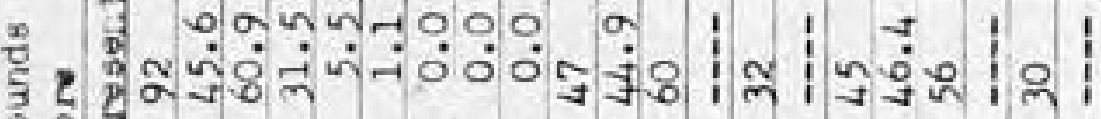

8.8

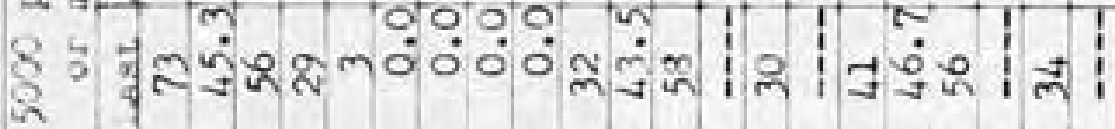

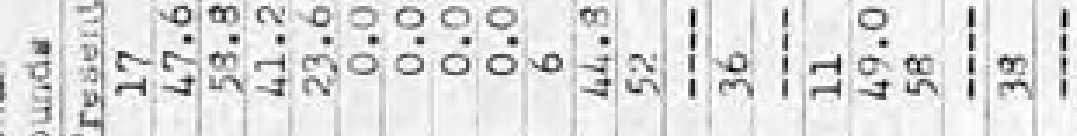

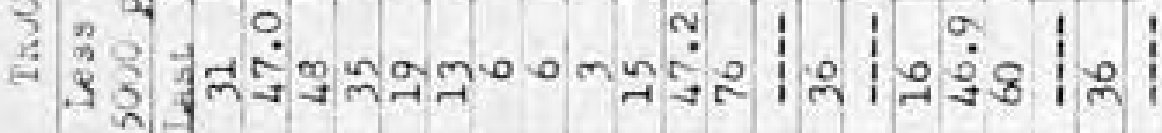

\section{$+$}

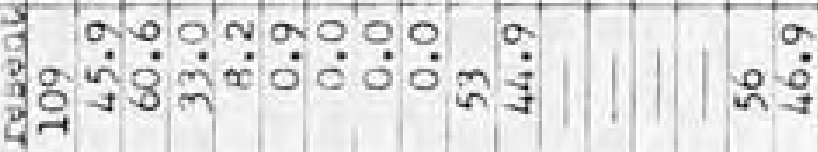

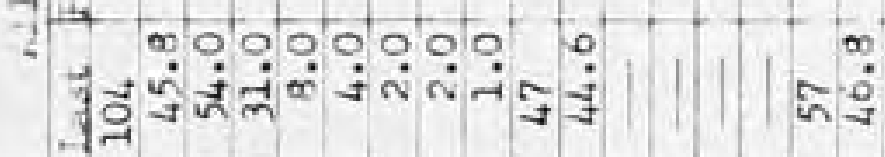

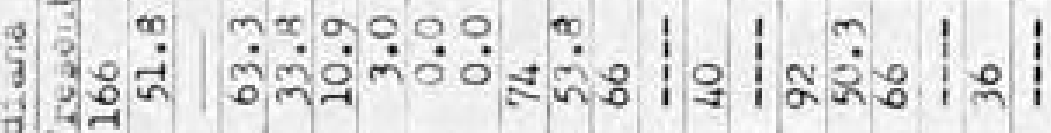

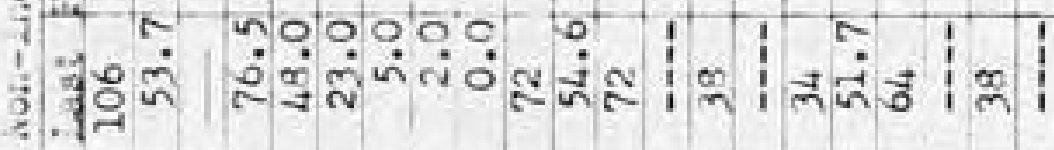

1

औำ

द) मेन

3)

+o. 0.000\%

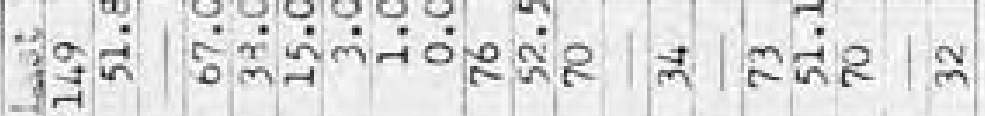

क्ष

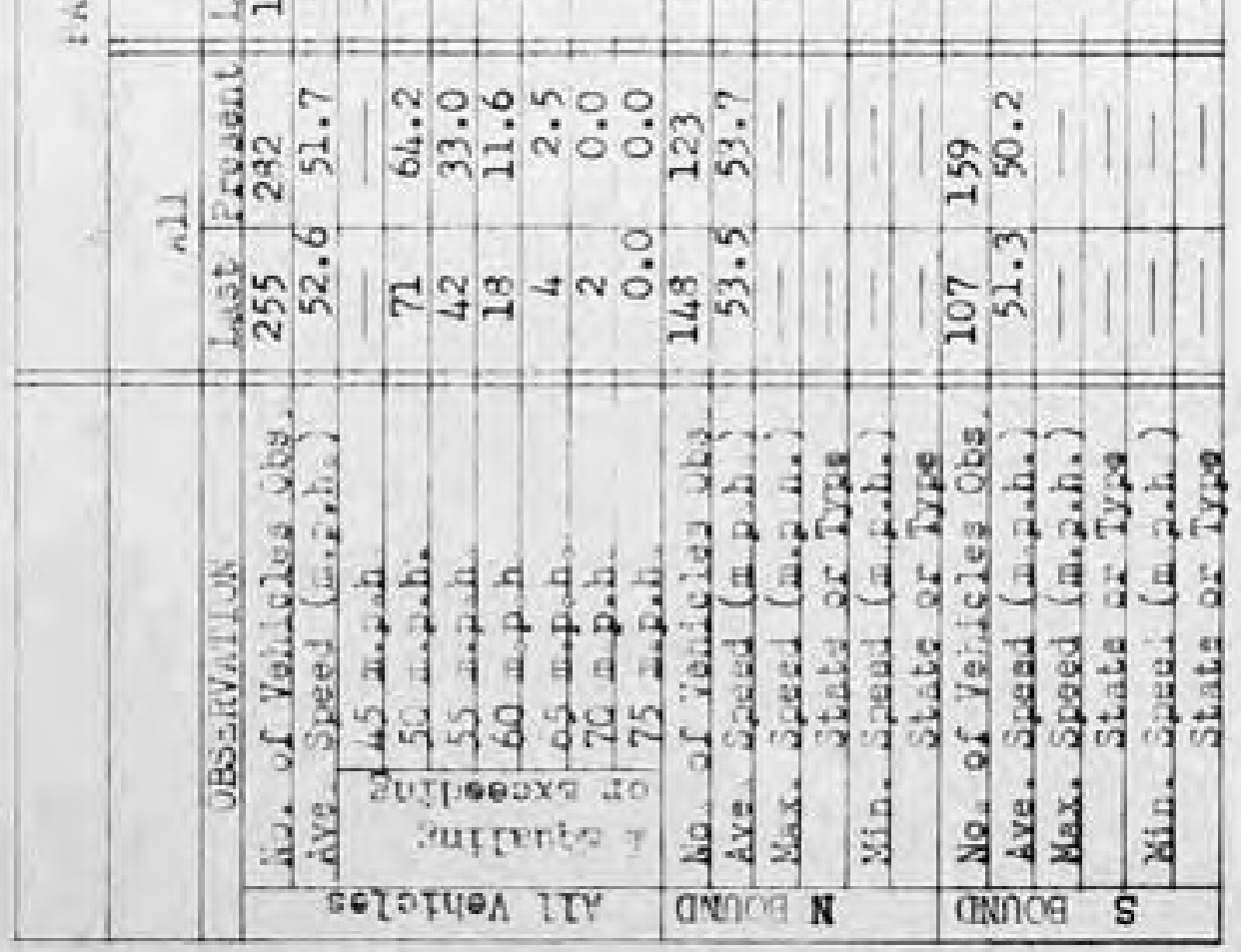




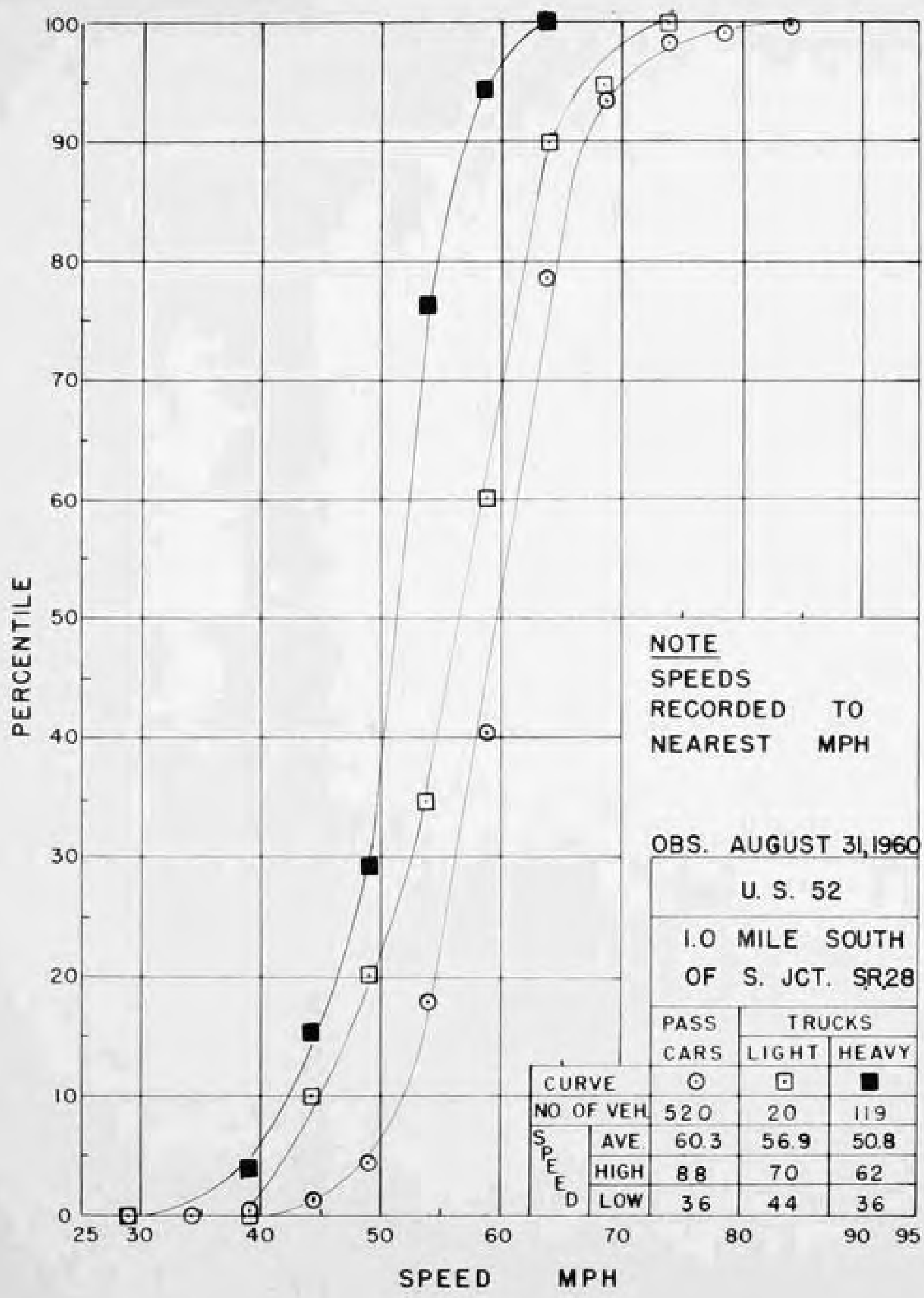

FIGURE I 


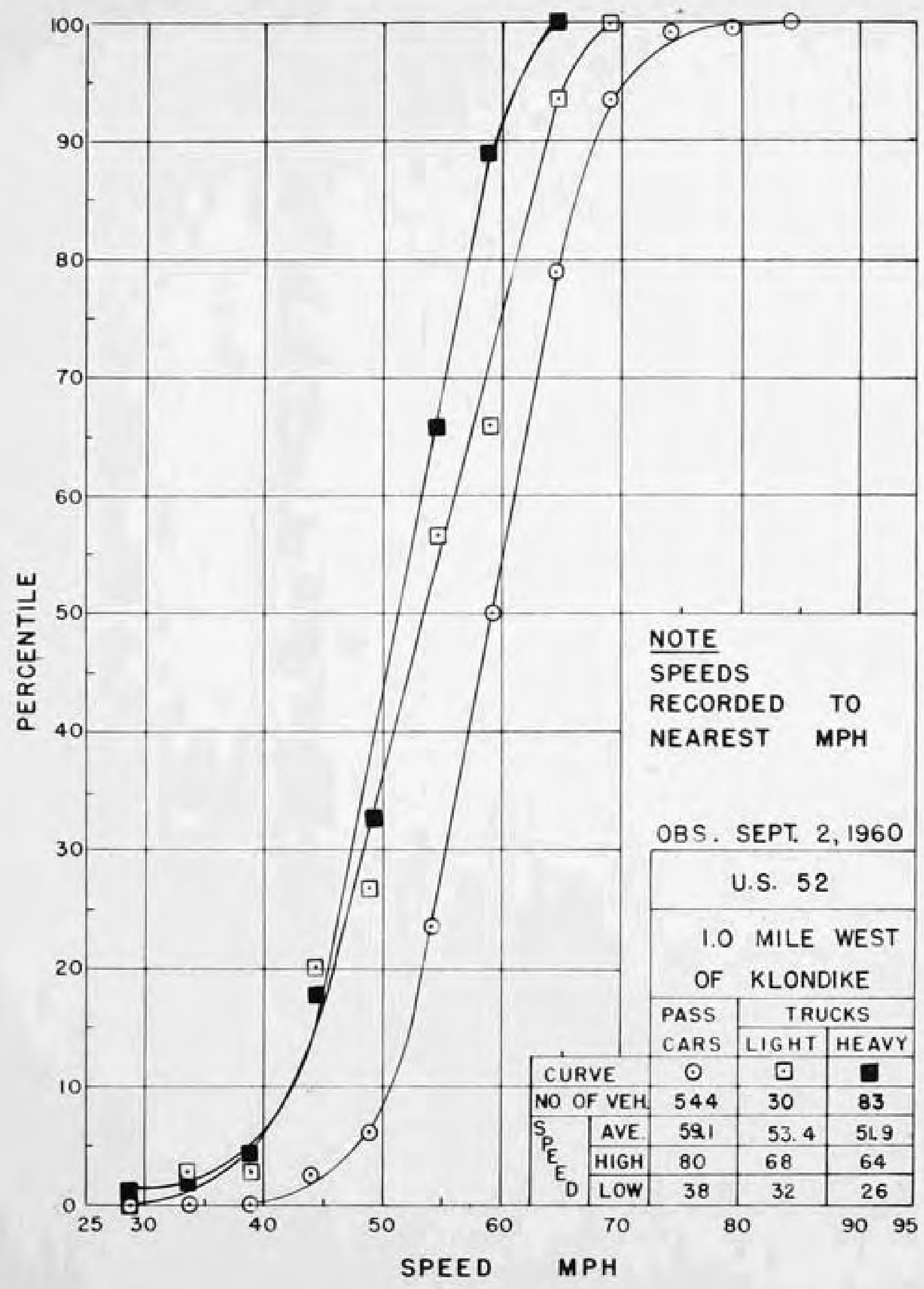

FIGURE 2 


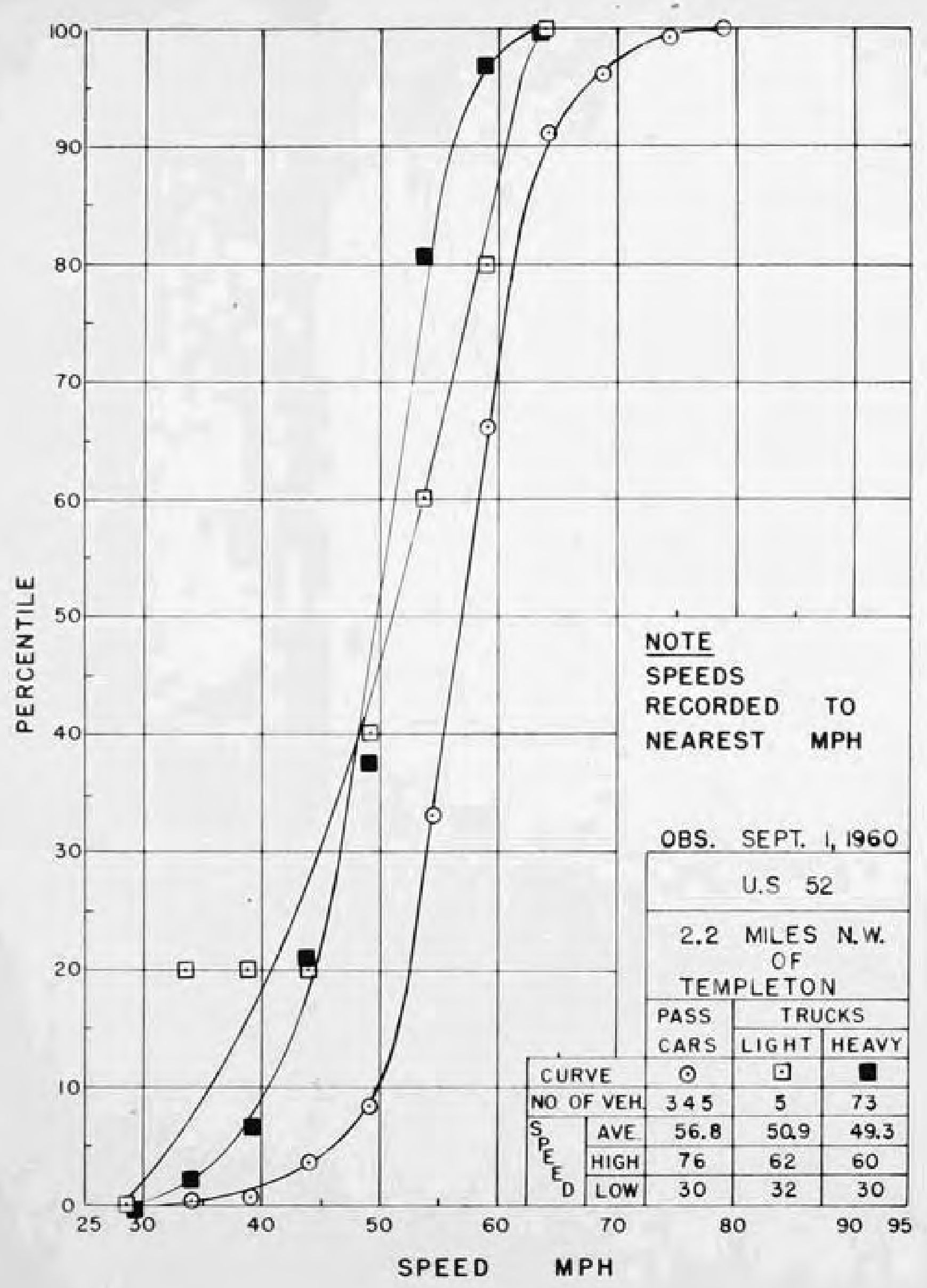

FIGURE 3 


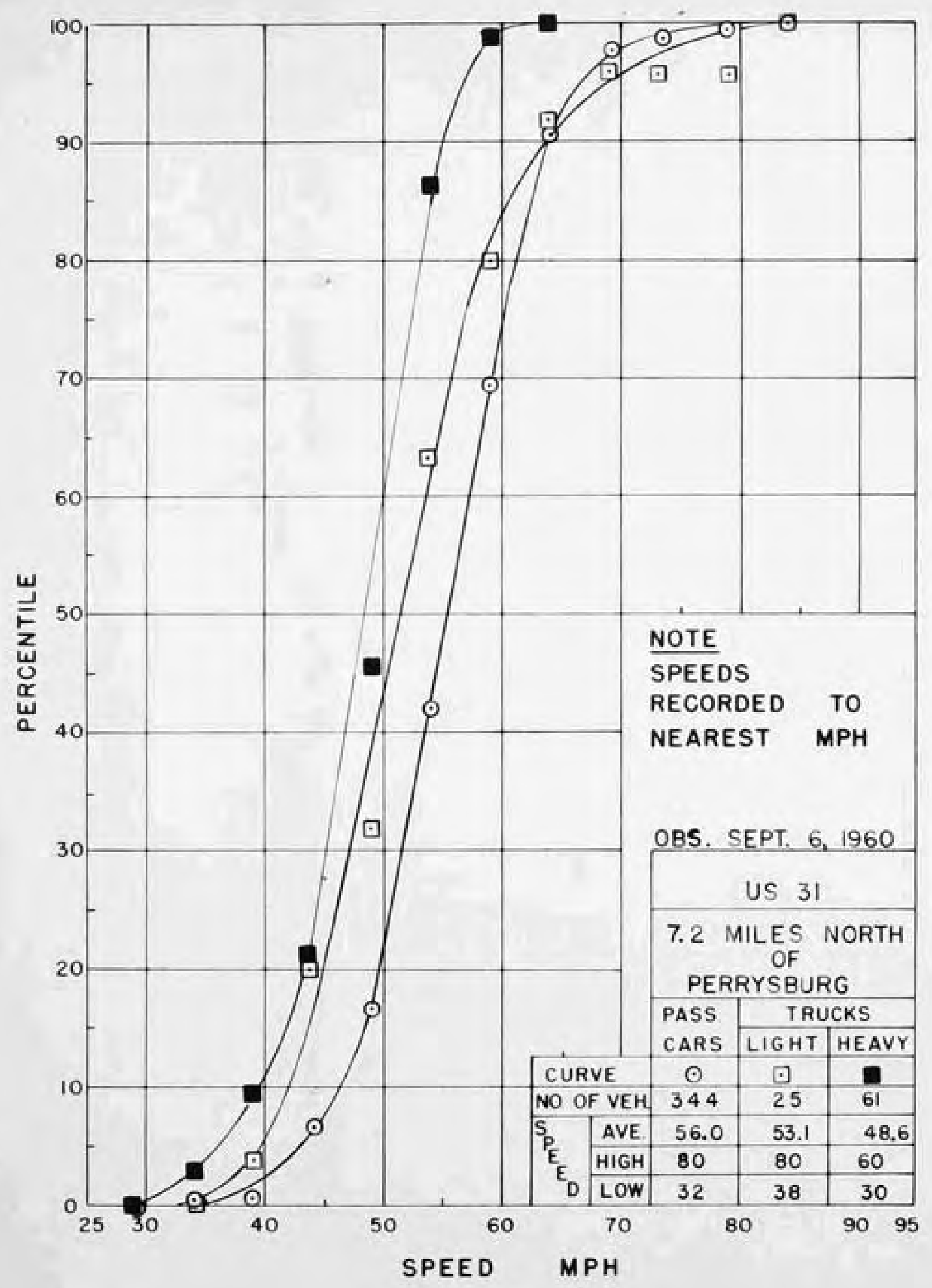

FIGURE 4 


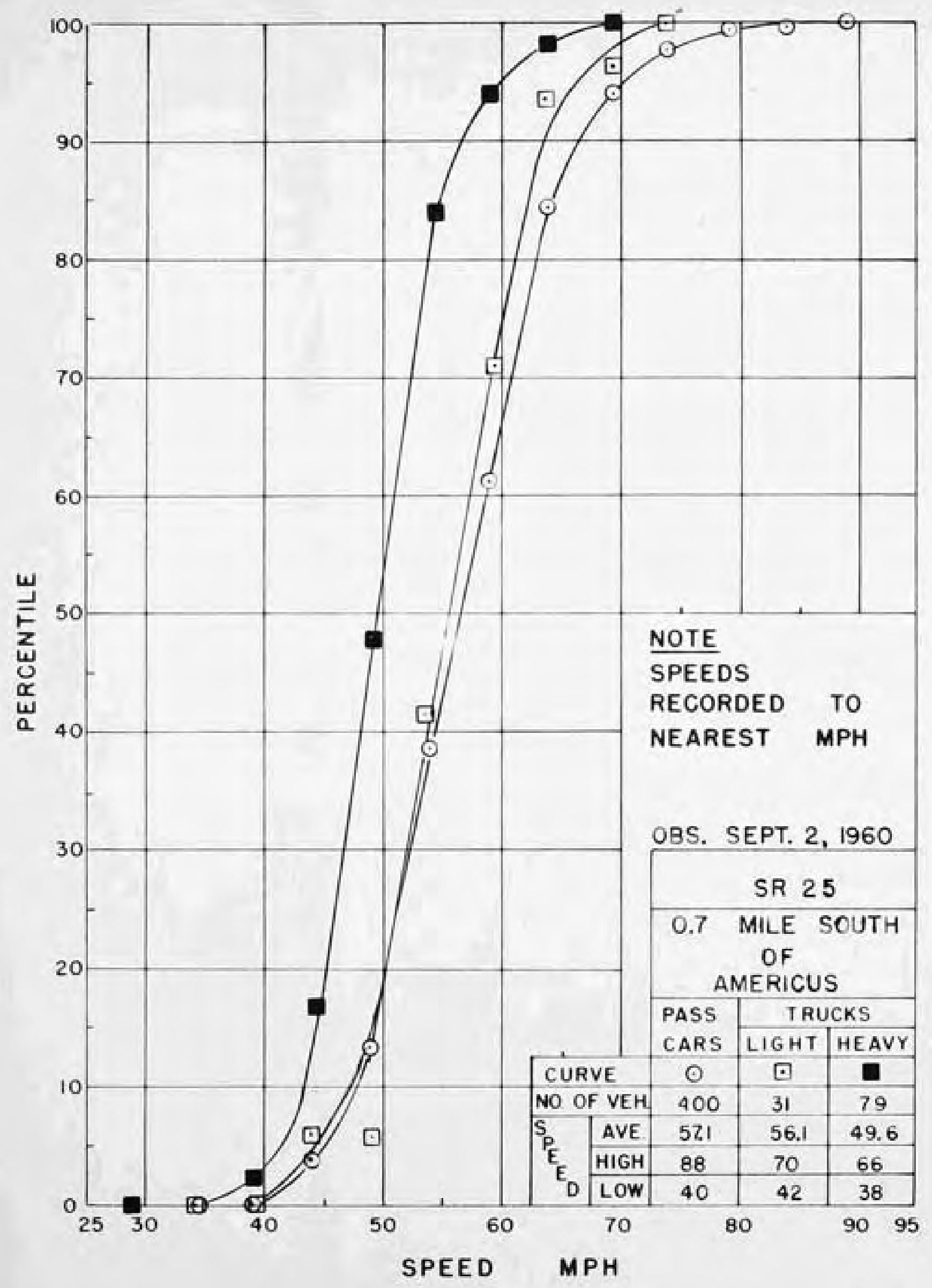

FIGURE 5 


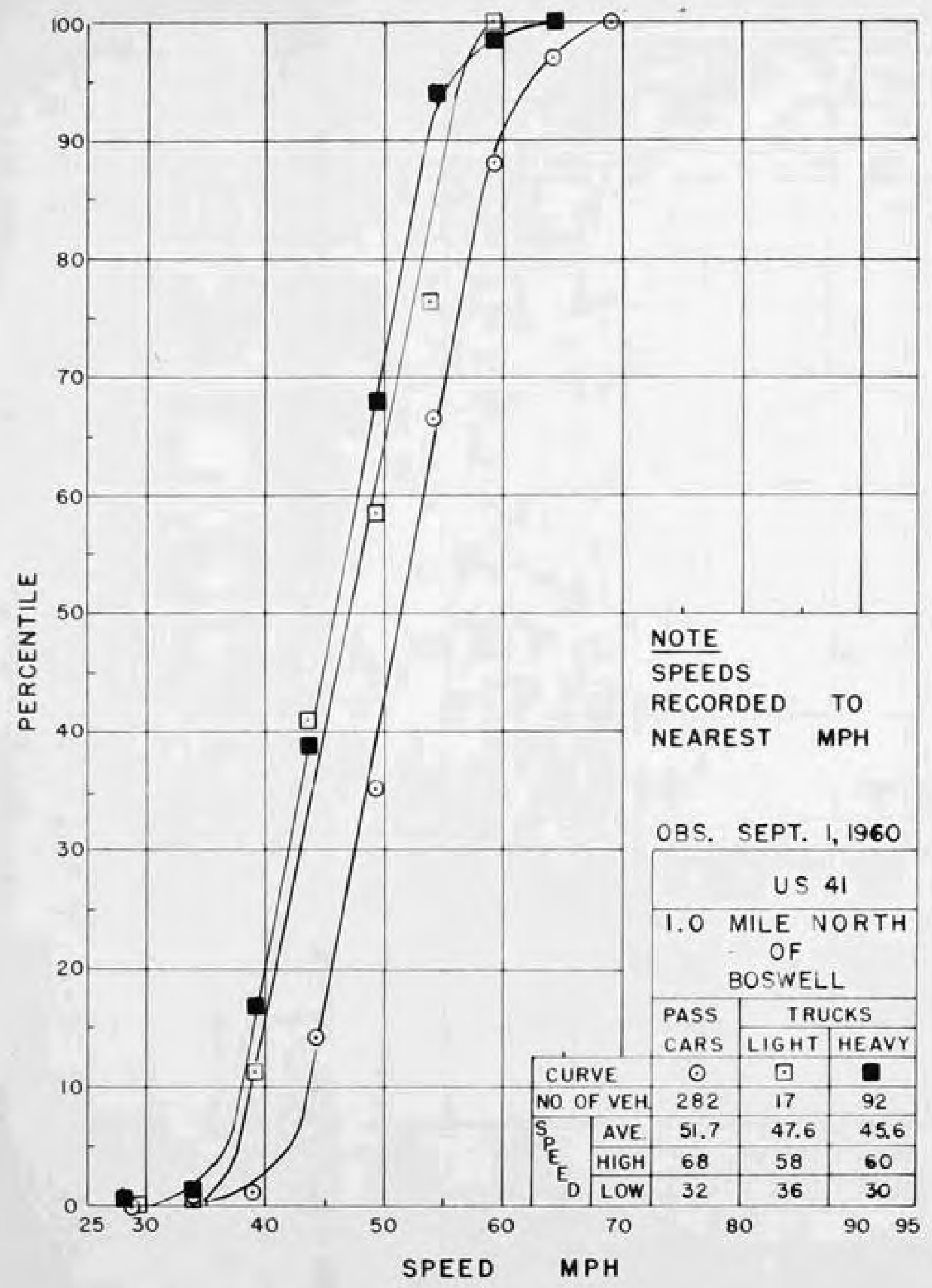

FIGURE 6 


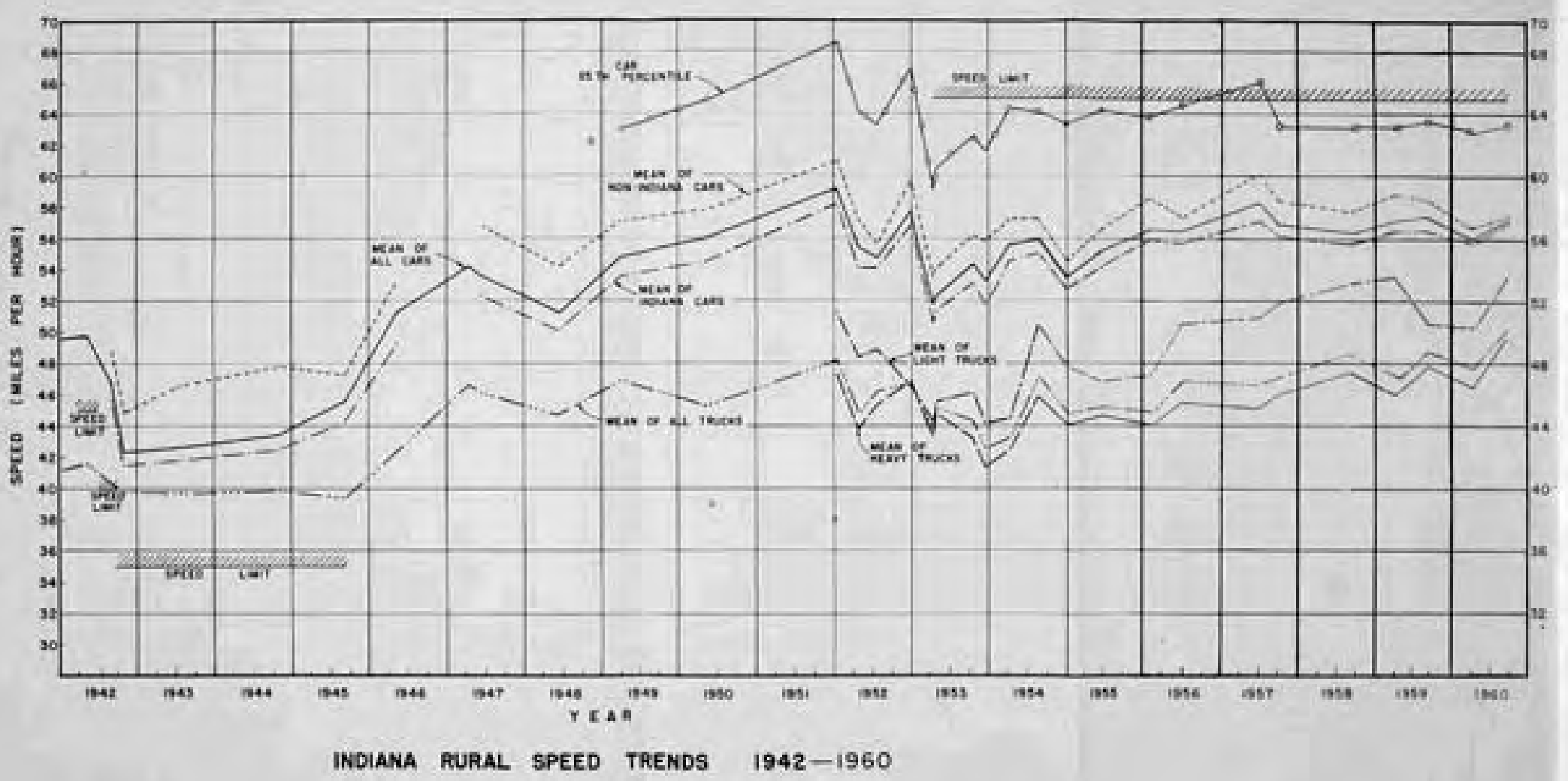

FIG 7 


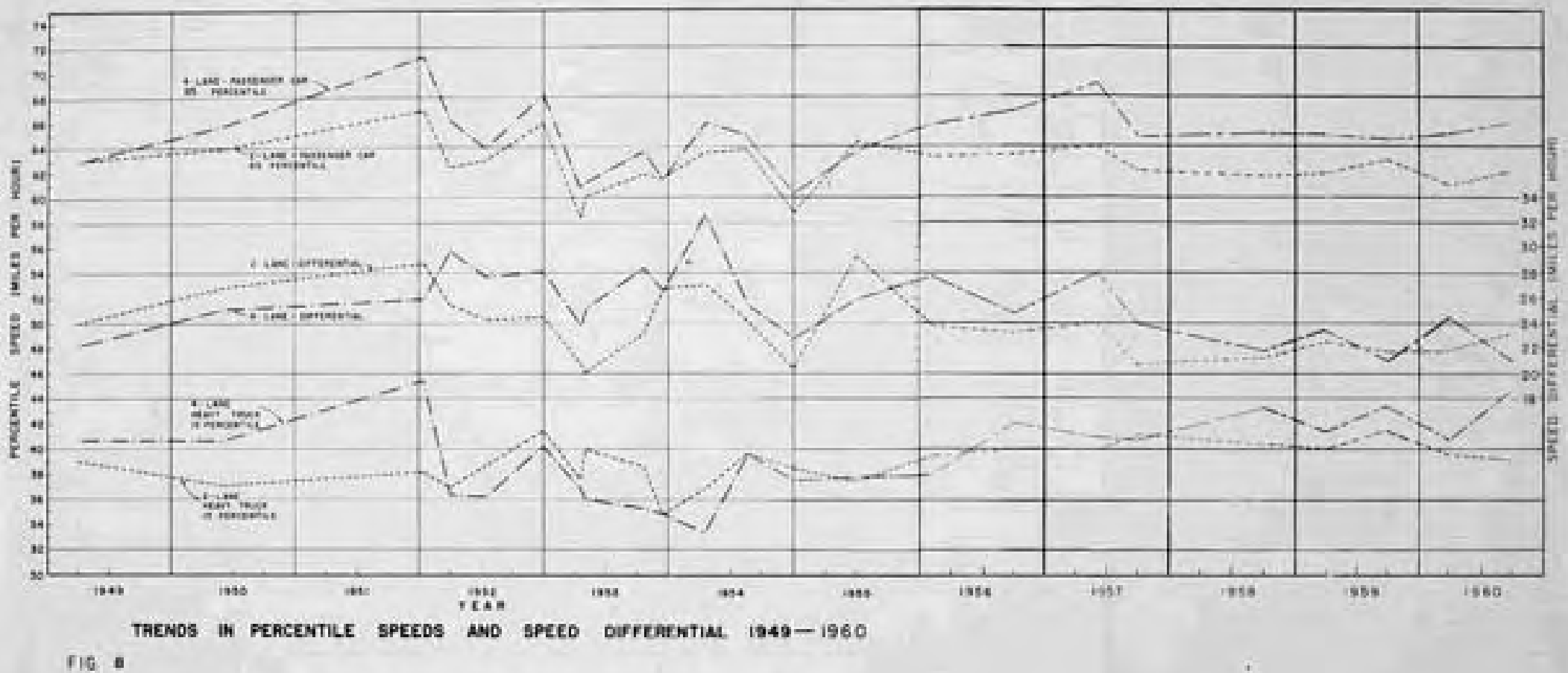

